\section{Acute intentional and accidental poisoning with medications in a southern Brazilian city}

\author{
Intoxicações medicamentosas agudas intencionais \\ e não intencionais notificadas em \\ município do Sul do Brasil
}

\author{
${ }_{1}$ Mestrado em Saúde \\ Coletiva, Universidade \\ Estadual de Londrina \\ Londrina, Brasil. \\ 2 Departamento de Saúde \\ Materno Infantil e Saúde \\ Comunitária, Universidade \\ Estadual de Londrina, \\ Londrina, Brasil. \\ 3 Departamento de Patologia \\ Aplicada, Universidade \\ Estadual de Londrina \\ Londrina, Brasil. \\ Correspondence \\ F. B. Margonato \\ Mestrado em Saúde Coletiva, \\ Universidade Estadual de \\ Londrina. \\ Rua José Clemente 1193, zona \\ 7, Maringá, $P R$ \\ 87020-070, Brasil. \\ fabianamargonato@yahoo.com.br
}

\begin{abstract}
The expansion of the pharmaceutical market in the $2^{\text {th }}$ century led to important changes in the consumption of medications worldwide. The objective of the current study was to analyze acute intentional and accidental poisoning with medications according to factors related to the individual, the poisoning, and the drug involved. This was a cross-sectional study that collected secondary data on all cases of acute poisoning with medications reported from 2003 to 2004 by the Poison Control Center at the Regional University Hospital in Maringá, Paraná State, Brazil. We studied a total of 546 cases of acute poisoning with medications. Females predominated among intentional cases (79.8\%), and the 0-9-year age bracket was the most common among accidental cases (51.9\%). The most frequently involved drugs were those acting on the central nervous system (57.2\%), predominantly those requiring controlled prescriptions, especially among the intentional cases (66.2\%). The results demonstrate the characteristics of acute poisoning from medications in Maringá, confirming the need for preventive measures that contribute to the rational use of medications.
\end{abstract}

Poisoning; Drugs; Drug Utilization
Fabiana Burdini Margonato 1

Zuleika Thomson 2

Monica Maria Bastos Paoliello 3

\section{Introduction}

Technological changes in the 20th century led to the extensive development of industries as a whole, fostering the synthesis of new compounds for various purposes 1 . In this context, the pharmaceutical industry developed rapidly, producing a vast array of new products and changes in the use of medications worldwide.

According to various authors, pharmaceutical products predominate in accidents resulting from exposure to toxic agents 2,3,4,5. In 2002, 26.9\% of poisonings recorded by the Brazilian national network of poison control centers involved pharmaceutical products 6 . In addition, Bochner 7, analyzing records from the National Toxicological and Pharmacological Data System (SINITOX), found that among poisonings reported in adolescence and pre-adolescence in Brazil from 1999 to 2001 , medications were among the main toxic agents.

The persistently high poisoning rates involving pharmaceutical products in Brazil reflect various forms of resistance to rational drug use. The existence of a huge variety of pharmaceuticals with dubious safety and efficacy can favor the indiscriminate sale and resulting over-utilization of these products, leading to the occurrence of harmful effects, often poisonings 8 .

In addition, the lack of initiatives to train health professionals to specifically provide adequate orientation on proper drug use leads to mis- 
information that can also foster incorrect use 8,9. In addition, the lack of information on drugs in the Hospital Data System of the Unified National Health System (SIH/SUS) and similar data systems favors the persistence of such misinformation 10. Meanwhile, the unnecessary use of prescription and non-prescription drugs is also a significant factor that increases the risk of poisonings 11 . The risks are thus obviously related to the level of information on medications among patients, prescribers, and dispensers 12,13,14.

Many health professionals are also unaware of the risk of poisoning from medication during their approach to users of medicines, further aggravating this risk. It is therefore necessary to study possible risk factors related to the occurrence of poisoning from medication in order to plan the appropriate preventive measures.

A study that characterizes intentional and accidental poisoning from medications can contribute to the design and implementation of health programs aimed at preventing these events and raising health professionals' awareness on their relevance for rational pharmaceutical use. Therefore, the aim of the current study was to analyze acute intentional and accidental poisoning from medications, according to factors related to the patient, the poisoning, and the drug involved.

\section{Methodology}

This was a cross-sectional epidemiological study of treatment provided by the Poison Control Center (CCI) in Maringá, Paraná State, Brazil, where secondary data were obtained for the period from January 2003 to December 2004.

The study population consisted of all individuals with a record of acute poisoning from medications during the study period. The sample excluded cases reported as adverse reactions, drug interactions, and those resulting from chronic use of medications, since they did not fit the objectives of the study, which analyzed acute poisonings. The sample also excluded non-residents of Maringá. Intentional cases were reported suicide attempts, abortion, homicide, and pharmaceutical drug abuse, while accidental cases were those reported as individual or collective accidents, incorrect use, incorrect medical prescription, and dosing errors. The data were obtained from poisoning forms from the CCI. The study was approved by the Institutional Review Board of the State University in Londrina, Paraná, as specified in case file 305/04.

The study focused on variables related to the individual, the poisoning, and the drug involved. Patient-related variables were gender and age at the time of poisoning, and those related to the poisoning were intention (intentional versus accidental), exposure route, and time of day and day of the week of the exposure. The variables related to the drug(s) involved were: amount, pharmacological class (according to the Anatomical Therapeutic Chemical Classification/Defined Daily Dose-ATC/DDD) 15, pharmaceutical form, and required control for dispensing.

Data were keyed in using Epi Info for Windows, version 3.2.2 (Centers for Disease Control and Prevention, Atlanta, USA). Simple frequencies and percentages were calculated to summarize the results.

\section{Results}

From January 2003 to December 2004, the Poison Control Center (CCI) in Maringá recorded 8,291 cases of poisoning. Of these, 1,112 (13.4\%) involved medications (733 residents of Maringá). We excluded 131 cases of adverse reactions and drugs interactions and 56 cases of poisoning from chronic-use medication, and the 546 remaining cases were studied. Of these, 209 (38.3\%) were reported as intentional and $337(61.7 \%)$ as accidental. Suicide attempts with medications were the most common (60.1\%). The second most common cause $(25.3 \%)$ involved individual accidents. Dosing errors, incorrect use, pharmaceutical drug abuse, incorrect medical prescription, attempted abortion, and homicide totaled $14.6 \%$.

As shown in Table 1, females comprised nearly $80 \%$ of intentional cases and slightly more than half of accidental cases. As for age, more than half of the accidental cases occurred in the 0-9-year group. There were also some intentional cases in early adolescence (10-14 years), while the largest number of intentional cases occurred in the 2039-year bracket (Table 2).

The vast majority of poisonings occurred by ingestion $(97.1 \%)$. While all the intentional cases resulted from ingestion of medicines, the accidental cases included a small percentage (7.7\%) indicating exposure by other routes (parenteral, nasal, transdermal, and ophthalmic).

As for time of exposure, $24.5 \%$ of the cases occurred from 6:00 PM to 11:59 PM. The largest share of both intentional and accidental cases ( $24.6 \%$ and $24.4 \%$, respectively) occurred during this time period. Among the intentional cases, the most common days were Sunday (19.2\%), Monday (15.6\%), and Saturday (15.5\%). Thursday (19.7\%) was the most common day for accidental poisoning with medications.

Drugs acting on the central nervous system were involved in the majority of intentional 
Distribution of acute poisonings with medications, according to gender and intention. Maringá, Paraná State, Brazil, 2003 and 2004.

\begin{tabular}{lcccccc}
\hline Gender & \multicolumn{2}{c}{ Accidental } & & Intentional & & Total \\
& $\mathbf{n}$ & $\%$ & $\mathbf{n}$ & $\%$ & $\mathbf{n}$ & \\
\hline Male & 99 & 47.6 & 68 & 20.2 & 167 & 30.6 \\
Female & 109 & 52.4 & 269 & 79.8 & 378 & 69.4 \\
Total & $208 *$ & 100.0 & 337 & 100.0 & 545 & 100.0
\end{tabular}

* Excludes one case with information missing.

Table 2

Distribution of acute poisonings with medications, according to intention and age bracket. Maringá, Paraná State, Brazil, 2003 and 2004 .

\begin{tabular}{|c|c|c|c|c|c|c|}
\hline \multirow{2}{*}{$\begin{array}{l}\text { Age bracket } \\
\text { (years) }\end{array}$} & \multicolumn{2}{|c|}{ Accidental } & \multicolumn{2}{|c|}{ Intentional } & \multicolumn{2}{|c|}{ Total } \\
\hline & $\mathrm{n}$ & $\%$ & $\mathrm{n}$ & $\%$ & $\mathrm{n}$ & $\%$ \\
\hline $0 \vdash 5$ & 126 & 60.3 & - & - & 126 & 28.7 \\
\hline $5 \vdash 10$ & 24 & 11.5 & - & - & 24 & 4.4 \\
\hline $10 \vdash 15$ & 14 & 6.7 & 24 & 7.2 & 38 & 7.0 \\
\hline $15 \vdash 20$ & 8 & 3.8 & 78 & 23.3 & 86 & 15.8 \\
\hline $20 \vdash 40$ & 19 & 9.1 & 178 & 53.1 & 197 & 36.2 \\
\hline $40 \vdash 60$ & 9 & 4.3 & 47 & 14.0 & 56 & 10.3 \\
\hline$\geq 60$ & 9 & 4.3 & 8 & 2.4 & 17 & 3.1 \\
\hline Total & 209 & 100.0 & 335 * & 100.0 & 544 & 100.0 \\
\hline
\end{tabular}

* Excludes two cases with information missing.

cases and slightly more than a third of the accidental cases (Table 3). Table 4 shows that the vast majority of accidental poisonings involved a single drug, as compared to slightly more than half of the intentional cases. As for pharmaceutical forms, Table 4 also shows that the proportion of solid forms of drugs was much higher among intentional cases, while liquid forms accounted for two-fifths of accidental poisonings. While the majority of accidental cases were caused by nonprescription medications, the opposite was true for intentional cases, two-thirds of which were related to ingestion of controlled drugs.

\section{Discussion}

The high number of acute intentional poisonings with medications among females was similar to the results in Marcondes Filho et al. 16, Juárez Aragón et al. 17, and González Valiente et al. 18, who observed that the majority of intentional cases occurred in females (although they were studying poisonings with chemical products in general).

As for age bracket, Bortolleto \& Bochner 19, analyzing SINITOX records on poisoning with medications in Brazil from 1993 to 1996, also found high intentional poisoning proportional rates in the 20-29-year age bracket (18.6\%). According to other authors, these percentages can be explained by difficulties in accessing the work market and personal and family problems, favoring the appearance of destructive forms of dealing with reality 20 . Bortoletto \& Bochner 19 found that the 0-4-year bracket had the highest proportion of poisonings with medications in Brazil from 1993 to 1996, with 33\%. More recent statistics for Brazil show $31.9 \%$, while a study using secondary data from the States of São Paulo and Rio Grande do Sul for 1997 and 1998 found $35.67 \% 21$. The differences between the percentage of poisonings in this age bracket in the current study and the data from the literature dem- 
Distribution of acute poisonings with medications, according to drug class and intention. Maringá, Paraná State, Brazil, 2003 and 2004.

\begin{tabular}{|c|c|c|c|c|c|c|}
\hline \multirow{2}{*}{$\begin{array}{l}\text { Drug class } \\
\text { (agents) }\end{array}$} & \multicolumn{2}{|c|}{ Accidental } & \multicolumn{2}{|c|}{ Intentional } & \multicolumn{2}{|c|}{ Total } \\
\hline & $\mathbf{n}$ & $\%$ & $\mathbf{n}$ & $\%$ & $\mathbf{n}$ & $\%$ \\
\hline Central nervous system & 112 & 43.3 & 354 & 63.7 & 466 & 57.1 \\
\hline Musculoskeletal system & 25 & 9.6 & 57 & 10.3 & 82 & 10.1 \\
\hline $\begin{array}{l}\text { Alimentary tract and } \\
\text { metabolism }\end{array}$ & 31 & 12.0 & 43 & 7.8 & 74 & 9.1 \\
\hline Cardiovascular & 25 & 9.6 & 47 & 8.4 & 72 & 8.8 \\
\hline Systemic anti-infective & 16 & 6.2 & 28 & 5.0 & 44 & 5.4 \\
\hline Respiratory system & 26 & 10.0 & 13 & 2.3 & 39 & 4.8 \\
\hline Others & 24 & 9.3 & 14 & 2.5 & 38 & 4.7 \\
\hline Total & 259 & 100.0 & 556 & 100.0 & 815 & 100.0 \\
\hline
\end{tabular}

Table 4

Distribution of acute poisonings with medications according to number of drugs involved, pharmaceutical form, control required for dispensing of drug(s), and intention. Maringá, Paraná State, Brazil, 2003 and 2004.

\begin{tabular}{|c|c|c|c|c|}
\hline \multirow[t]{2}{*}{ Variable } & \multicolumn{2}{|c|}{ Accidental } & \multicolumn{2}{|c|}{ Intentional } \\
\hline & $\mathbf{n}$ & $\%$ & $\mathrm{n}$ & $\%$ \\
\hline \multicolumn{5}{|l|}{ Number of drugs involved } \\
\hline 1 & 191 & 91.4 & 195 & 57.9 \\
\hline 2 or more & 17 & 8.1 & 131 & 38.9 \\
\hline No information available & 1 & 0.5 & 11 & 3.2 \\
\hline Total & 209 & 100.0 & 337 & 100.0 \\
\hline \multicolumn{5}{|l|}{ Pharmaceutical form } \\
\hline Solid & 115 & 55.0 & 292 & 86.6 \\
\hline Liquid & 85 & 40.7 & 8 & 2.4 \\
\hline Solid and liquid & 1 & 0.5 & 9 & 2.7 \\
\hline No information available & 8 & 3.8 & 28 & 8.3 \\
\hline Total & 209 & 100.0 & 337 & 100.0 \\
\hline \multicolumn{5}{|l|}{ Type of control required for dispensing } \\
\hline Controlled prescription & 62 & 29.7 & 223 & 66.2 \\
\hline Without controlled prescription & 144 & 68.9 & 100 & 29.7 \\
\hline No information available & 3 & 1.4 & 14 & 4.1 \\
\hline Total & 209 & 100.0 & 337 & 100.0 \\
\hline
\end{tabular}

onstrate the need for new studies with specific methodological approaches to accidents with medications in this preschool age group.

The high percentage of accidental poisonings in childhood may be related to the natural tendency of children to explore their environment and place whatever they find in their mouths 22 . In the United States and Canada, a measure that reduced the rates of accidental poisoning with medications was the mandatory use of special child-proof caps on medications and household cleaning products. Brazil has a Federal Bill of Law (4.841/1994), first submitted in 1994, to implement such child-proof medicine bottles, but thus far the National Congress has failed to pass it 23 . The production of special child-proof bottles, the implementation of educational programs on poisoning hazards in schools and daycare centers, 
and parent and teacher awareness-raising on proper care and handling of medications could reduce such drug-related accidents in childhood.

The percentage of adolescents among the intentional cases could be explained by hypotheses raised in Londrina, Paraná State, Brazil, by Marcondes Filho et al. 16, who observed that the most important factors related to suicide attempts by poisoning in the 12-24-year group were interpersonal losses, depression, and drug abuse. Interestingly, according to Bochner 7, from 1999 to 2001 in Brazil, medications accounted for $33 \%$ of reported poisonings among adolescents aged 15 to 19 . The same author found that in the 1014-year group, this percentage was lower (25.7\%), while other, non-pharmaceutical products were more common.

Some authors feel that the problem of suicide attempts in adolescence is due to the biological, psychological, and social changes that occur during this period of life 7,24 . The work by physicians specializing in adolescence has been emphasized in health services and recommended by Teixeira \& Luis 24 . Another factor cited by authors is the need for health professionals that are prepared to recognize risk behaviors among adolescents and youth. Educational programs and early specialized care for family members and friends are also recommended, although families often show resistance, since the potentially suicide-prone individual may have requested help in some way and gone unnoticed 24 .

As for type of event, although the available data for 2002 in the SINITOX databank show methodological differences as compared to the current study, since they also include poisonings from chronic-use medications, the most common circumstances were also suicide attempts and individual accidents $(39.5 \%$ and $37.8 \%$, respectively) in Brazil 6 . Although the findings are consistent with ours, importantly, the suicide attempt rate in Maringá was nearly double the Brazilian national rate.

In a previous study in Maringá on poisonings in general in the 0-14-year-old population, ingestion occurred in $79.3 \%$ of the cases 25 , a lower figure than in the current study. Meanwhile, Oduardo Lorenzo et al. 26 found that among acute poisonings in the $0-15$-year bracket, $93.4 \%$ occurred by ingestion, similar to the findings by Gárate et al. 27 (91.5\%). In Porto Alegre, Rio Grande do Sul State, Brazil, $88.4 \%$ of cases in children $0-5$ years of age were by ingestion 18 . Gandolfi \& Andrade 28 showed similar findings in the State of São Paulo in 1998. The high rates of accidental cases near lunch time (10:00 AM to 1:59 PM) and dinner time (6:00 PM to 11:59 PM), could be ex- plained by the fact that colorful medicines are often stored in the kitchen, a situation prone to accidental poisoning in children.

The high rate of liquid pharmaceutical preparations among accidental cases could be related to the study population's characteristics, since more than $70 \%$ occurred in children less than ten years old (Table 2). Techniques that facilitate the use of medications by children resistant to swallowing drugs are important for various medical treatments in this age bracket. However, the manufacturing of easy-to-open, colored packages that contain medicines with attractive colors and smells could unwittingly facilitate childhood poisonings.

The high percentage of intentional cases on Sundays could result from family and conjugal strife related to weekends, like alcohol abuse, more time spent with the family, anxiety, loneliness, and other factors. In Londrina, Marcondes Filho et al. 16 observed that suicide attempts by poisoning were positively associated with alcohol and drug abuse, more frequent on weekends.

Meanwhile, in studies on family problems related to suicide attempts, some authors concluded that depression is be related to family conflicts like difficulty with adaptation, disharmony, disorganization, demoralization, and family breakdown 29,30 . Such types of family conflicts often become more evident when the family spends more time together, that is, mainly on Sundays. Such factors could explain the higher percentage of suicide attempts with medications on this day of the week.

Consistent with the current study, the research by Marcondes Filho et al. 16 point to the predominance of ingestion of drugs acting on the central nervous system in intentional cases of poisoning. Likewise, analyzing acute poisoning with medications in the State of São Paulo in 1998, Gandolfi \& Andrade 28 also found that drugs for treatment of psychiatric and neurological disorders were the most common pharmacological groups among poisonings. A Cuban study showed similar results, based on data from 1995 and $1996{ }^{31}$.

The percentage of central-acting medications among poisonings is worrisome, since this type of drug nearly always requires a prescription for dispensing. The prescription of indiscriminate doses, dispensing without adequate information, and even sales without a prescription may be related to improper use. Some authors point to the fact that depressive patients are often prone to suicide attempts 16 . Thus, especially in these cases, prescriptions should be rationalized, with indication of the adequate amounts, in order to ensure the correct use of such drugs. 
Indiscriminate self-medication, with high rates reported in Brazilian studies, is believed to have favored the high rates of accidental poisonings 11,32,33. The high rate of poisonings with multiple drugs may be related to the ease in obtaining medications on the Brazilian market 13 . This frequency may be associated with lack of information and awareness and to abusive advertising by the pharmaceutical industry, favoring the accumulation of small home pharmacies 27,29. In studies evaluating knowledge on generic drugs in Pelotas (Rio Grande do Sul) 14 and Recife (Pernambuco) 13 , the authors concluded that schooling and purchasing power bear a positive association with level of knowledge on these products. They also found that older age was associated with lower level of information on medications, and that lack of information can lead to non-utilization of generic drugs or inadequate interchange between brand-name and generic products 13,14 . Based on this information, one can assume that lack of orientation can also lead to incorrect use of medications, furthering increasing the odds of poisonings. Some authors have also highlighted that the elderly population is highly susceptible to such misinformation 34 .

In relation to the drugs used in self-medication, specifically over-the-counter drugs, their purchase in pharmacies without a prescription would probably not be so problematic if the pharmacist always dispensed them 14 . However, the simple presence of a trained professional in dispensing sites would be useful, as long as the proper orientation on risk of poisonings was communicated to the purchaser.

The results of the present study allow concluding that the great majority of intentional cases of poisoning occurred in females, while 0-9 years was the most common age bracket for accidental cases, and intentional cases prevailed in the other age brackets. Sunday was the most common day of the week for intentional case and Thursday for accidental cases. For all cases, the most frequent clinical outcome was cure without signs or symptoms.

In relation to the drugs involved, the percentage of poisonings with multiple drugs was higher in intentional cases, and the most frequent drugs were those acting on the central nervous system. Liquid pharmaceutical preparations were more frequent among accidental poisonings, and controlled-use prescription drugs were more common among intentional cases.

This study's findings show that poisonings with medications pose a large-scale problem during both childhood and adulthood. The conclusion is that the implementation of educational programs on the prevention of household accidents, focusing on mothers, the distribution of information leaflets in drugstores and primary health clinics, and correct orientation on the proper storage and use of drugs are also important tools for changing this reality.

For adults, an important measure to prevent suicide attempts with medications is the effective monitoring and inspection of sales on controlled drugs by pharmacies. The prescription of exaggerated amounts of such medications to depressive patients is believed to favor their use in suicide attempts. Standardization of the prescribed amounts is recommended, along with the availability of psychological follow-up for these individuals by the health system.

Given the reality as observed above, it is believed that proper training of health professionals to provide orientation on the correct use and storage of medications can greatly reduce the rates of acute poisoning with medications in the general population. Effective multidisciplinary work and exchange of information by health teams is essential for the prevention, detection, treatment, reporting, and follow-up of poisonings. 


\section{Resumo}

A proliferação do mercado farmacêutico no século XX propiciou mudanças importantes no consumo de medicamentos em todo o mundo. O objetivo do presente estudo foi analisar as intoxicações medicamentosas agudas intencionais e não intencionais segundo fatores relacionados ao intoxicado, à intoxicação e ao medicamento envolvido. Trata-se de um estudo transversal, com coleta de dados secundários referentes a todos os casos de intoxicações medicamentosas agudas notificadas em 2003 e 2004 pelo Centro de Controle de Intoxicações do Hospital Universitário Regional de Maringá, Paraná, Brasil. Foram estudados 546 casos de intoxicações medicamentosas agudas. O sexo feminino foi o mais acometido nos casos intencionais (79,8\%), e a faixa etária de 0-9 anos foi predominante entre as intoxicações não intencionais (51,9\%). Os medicamentos mais freqüentemente envolvidos foram os de ação no sistema nervoso central (57,2\%), com predomínio de fármacos que requerem retenção de receita na dispensação, principalmente entre os casos intencionais $(66,2 \%)$. Os resultados evidenciaram as características das intoxicações medicamentosas agudas em Maringá, confirmando a necessidade da implantação de medidas preventivas que contribuam para a utilização racional de medicamentos.

Envenenamento; Medicamentos; Uso de Medicamentos

\section{References}

1. Amaral DA, Barcia SAD. Intoxicações por medicamentos. In: Oga S, organizador. Fundamentos de toxicologia. 2a Ed. São Paulo: Editora Varella; 2003. p. 367-79.

2. Andrade Filho A, Campolina D, Dias MB. Toxicologia na prática clínica. Belo Horizonte: Editora Folium; 2001.

3. Bortoletto ME. Tóxicos, civilização e saúde: contribuição à análise dos sistemas de informações tóxico-farmacológicas no Brasil. Rio de Janeiro: Editora Fiocruz; 1993

4. Klaassen CD. Princípios da toxicologia e tratamento do envenenamento. In: Gilman AG, Hardman JG, Limbird LE, editors. Goodman \& Gilman: as bases farmacológicas da terapêutica. 10a Ed. New York: McGraw-Hill; 2003. p. 51-61.

5. Schvarzsman S. Intoxicações agudas. 3a Ed. São Paulo: Editora Sarvier; 1991.

\section{Contributors}

F. B. Margonato was responsible for elaborating the research project, collecting, tabulating, and analyzing the data, and writing the article. Z. Thomson oriented the research work and was responsible for elaborating the research project, the data analysis, and writing of the article. M. M. B. Paoliello acted as joint supervisor of the research and contributed significantly to the data analysis and writing of the article.
6. Sistema Nacional de Informações Tóxico-Farmacológicas. Casos registrados de intoxicação humana e envenenamento: Brasil, 2002. http://www. fiocruz.br/sinitox/intoxicacoeshumana/2002/ umanalise.htm (accessed on 06/Jul/2005).

7. Bochner R. Perfil das intoxicações em adolescentes no Brasil no período de 1999 a 2001. Cad Saúde Pública 2006; 22:587-95.

8. Consendey MAE, Hartz ZMA, Bermudez JAZ. Validation of a tool for assessing the quality of pharmaceutical services. Cad Saúde Pública 2003; 19:395-406.

9. Silva CDC, Coelho HLL, Arrais PSD, Cabral FR. Centro de informação sobre medicamentos: contribuição para o uso racional de fármacos. Cad Saúde Pública 1997; 13:531-5.

10. Rozenfeld S. Agravos provocados por medicamentos em hospitais do estado do Rio de Janeiro, Brasil. Rev Saúde Pública 2007; 41:108-15. 
11. Arrais PSD. O uso irracional de medicamentos e a farmacovigilância no Brasil. Cad Saúde Pública 2002; 18:1478-9.

12. Arrais PSD, Coelho HLL, Batista MCDS, Carvalho ML, Righi RE, Arnau JM. Perfil da automedicação no Brasil. Rev Saúde Pública 1997; 31:71-7.

13. Rocha CE, Barros JAC, Silva MDP. Levantamento de dados sobre o conhecimento e informação acerca dos medicamentos genéricos em uma população de pacientes do serviço de saúde ambulatorial do Recife, Pernambuco, Brasil. Cad Saúde Pública 2007; 23:1141-50.

14. Bertoldi AD, Barros AJD, Hallal PC. Generic drugs in Brazil: known by many, used by few. Cad Saúde Pública 2005; 21:1808-15.

15. WHO Collaborating Centre for Drug Statistics Methodology. ATC/DDD index 2005. http://www. whocc.no/atcddd/ (accessed on 01/Sep/2005).

16. Marcondes Filho W, Mezzaroba L, Turini CA, Koike A, Motomatsu Junior A, Shibayama EEM, et al. Tentativas de suicídio por substâncias químicas na adolescência e juventude. Adolesc Latinoam 2002; 3:0-0.

17. Juárez Aragón G, Castañón González JÁ, Pérez Morales AJ, Montoya Cabrera MA. Características clínicas y epidemiológicas de intoxicaciones graves en un a población adulta que ingresa a una unidad de cuidados intensivos. Gac Méd Méx 1999; 135:669-75.

18. González Valiente ML, Conill Díaz T, Pérez Salgado R. Incidencia de las intoxicaciones agudas. Rev Cuba Med Gen Integr 1999; 15:24-31.

19. Bortoletto ME, Bochner R. Impacto dos medicamentos nas intoxicações humanas no Brasil. Cad Saúde Pública 1999; 15:859-69.

20. Romão MR, Vieira LJES. Tentativas de suicídio por envenenamento. Rev Bras Promoção Saúde 2004; 17:14-20.

21. Matos GC, Rozenfeld S, Bortoletto ME. Intoxicações medicamentosas em crianças menores de cinco anos. Rev Bras Saúde Matern Infant 2002; 2:167-76.

22. Ramos CLJ, Targa MBM, Stein AT. Perfil das intoxicações na infância atendidas pelo Centro de Informação Toxicológica do Rio Grande do Sul (CIT/ RS), Brasil. Cad Saúde Pública 2005; 21:1134-41.

23. Brasil. Projeto de Lei ${ }^{\circ}$. 4.841, de 30 de novembro de 1994. Determina a utilização de embalagem especial de proteção à criança - EEPC - em medicamentos e produtos químicos de uso doméstico que apresentem potencial de risco à saúde. Brasília: Congresso Nacional; 1994.
24. Teixeira AMF, Luis MAV. Distúrbios psiquiátricos, tentativas de suicídio, lesões e envenenamento em adolescentes atendidos em uma unidade de emergência, Ribeirão Preto, São Paulo, 1988-1993. Cad Saúde Pública 1997; 13:517-25.

25. Amador JC. Perfil das intoxicações infantis no município de Maringá [Masters Thesis]. Londrina: Universidade Estadual de Londrina; 1997.

26. Oduardo Lorenzo M, Martínez Cabrera J, Ramírez Muñoz S. Eventos tóxicos en la infancia según consultas telefónicas atendidas en el centro nacional de toxicología (1994-1997). Rev Cuba Pediatr 1999; 71:80-5.

27. Gárate NO, Cendoya CU, Zegers CC, Fernandéz EL, Alfaro JO, Diaz MT. Exposiciones a sustancias tóxicas en el Servicio de Urgencia Infantil del Hospital Doctor Félix Bulnes Cerda. Rev Chil Pediatr 2002; 73:257-62.

28. Gandolfi E, Andrade MGG. Eventos toxicológicos relacionados a medicamentos no estado de São Paulo. Rev Saúde Pública 2006; 40:1056-64.

29. Guibert Reyes W, Torres Miranda N. Intento suicida y funcionamiento familiar. Rev Cuba Med Gen Integr 2001; 17: 452-60.

30. Herrera Santi PM, Avilés Betancourt K. Factores familiares de riesgo en el intento suicida. Rev Cuba Med Gen Integr 2000; 16:134-7.

31. González Valiente ML, Pérez Echemendia JO, González Delgado CA, Capote Marrero B. Mortalidad por intoxicaciones agudas producidas con medicamentos. Cuba, 1995-1996. Rev Cuba Farm 2000; 34:25-33.

32. Castro LLC, Costa AM, Kozoroski AM, Rossini A, Cymrot R. Algumas características da prática da automedicação em Campo Grande, Mato Grosso do Sul. Rev Ciênc Farm 2000; 21:81-101.

33. Loyola Filho AI, Uchoa E, Guerra HL, Firmo JOA, Lima-Costa MF. Prevalência e fatores associados à automedicação: resultados do Projeto Bambuí. Rev Saúde Pública 2002; 36:55-62.

34. Souza AC, Lopes MJM. Práticas terapêuticas entre idosos de Porto Alegre: uma abordagem qualitativa. Rev Esc Enferm USP 2007; 41:52-6.

Submitted on 17/Aug/2007

Final version resubmitted on $22 / \mathrm{Jan} / 2008$ Approved on 28/Feb/2008 